\title{
A prostitúció megítélése a résztvevők szemével
}

\section{KOVÁCS ISTVÁN ${ }^{1}$}

A tanulmány egy olyan 2018-ban készült és eredményeit összesitő alapkutatás konklúzióit mutatja be, amely a magyarországi prostitúció jogi és társadalmi helyzetét az abban részt vevő személyek megélt valóságán keresztül szemlélteti. Végre teljes képet kaphatunk a tekintetben, hogy a prostitúcióval foglalkozó személyek mindennapjaikat hogyan élik, a jelenlegi szabályozás életükre és munkakörnyezetükre milyen hatást gyakorol, munkájuk során milyen visszaélésekkel kell szembesülniük, és hogy vajon a prostituáltak továbbra is a társadalom megtürt, és perifériára sodródott marginalizált csoportjai-e, vagy az elöitéletek helyére az elfogadás és a tolerancia lépett. Mindezt kvantitatív módszerekkel végzett kutatás keretében vizsgálom.

Kulcsszavak: prostitúció, kvantitatív kutatás, jogi szabályozás, reintegráció, társadalom

\section{Judging Prostitution through the Eyes of Participants}

The study presents the conclusions of a basic research conducted in year 2018 and summarises its results, which illustrate the legal and social situation of prostitution in Hungary through the lived reality of the people involved in it. We can finally get a complete picture of how prostitutes live their daily lives, how current regulations affect their lives and work environments, what abuses they face in their work, and whether prostitutes remain marginalised and marginalised in society groups, or prejudices were replaced by acceptance and tolerance. I examine all this in the framework of a quantitative research.

Keywords: prostitution, quantitative research, legal regulation, reintegration, society

\section{Bevezetés}

Jelen tanulmányban azt vizsgálom, hogy vajon a prostituáltak valóban a társadalom kirekesztettjei-e, valóban egy olyan marginalizált csoportról van-e szó,

1 PhD, hivatásos állományú rendőrtiszt, az NKE RTK Rendészeti Vezetéstudományi Tanszékének tanársegédje, a Rendészettudományi Doktori Iskola tudományos titkára. 
akiket a társadalom kitaszított magából, vagy egy olyan sztereotípiával állunk szemben, amelyet az évek alatt a társadalom csak ráaggatott e személyekre.

Elsőként alapkutatást folytattam, amelynek során a rendelkezésre álló primer és szekunder forrásokat elemeztem. Azokat levéltári, múzeumi, könyvtári és online forrásokból gyüjtöttem össze. (Az analízis, a szintézis és a forráskritika alkalmazása segítségül volt abban, hogy azokat részleteiben vizsgálni tudjam.) Ennek végeztével egy absztraktálható, generális konklúziót kaptam, amit a kutatásom során kapott eredményekkel összevethettem. A saját tudományos eredményeim kvantitatív metóduson alapuló kutatásból származnak, amelynek során 100 (prostituált) résztvevő egy anonim kérdőívet töltött ki, az így kapott eredmények alapján pedig hipotéziseimet matematikai statisztikai próbákkal teszteltem és hitelesítettem. A kutatás az előzőek alapján lehetővé tette a társadalmi kirekesztettség okainak a prostituáltak szemszögéből való feltárását. Megjegyzendő, hogy a jelenség komplexitására tekintettel a különböző tudományterületek (orvostudomány, rendészettudomány, gazdaságtudomány stb.) a prostitúció mibenlétének megértéséhez éppúgy hozzájárulnak, de annak alapját, az elsődleges információkat kizárólag a prostitúcióval közvetlenül kapcsolatba hozható személyektől szerezhetjük be, akik saját tapasztalataikkal színesítik e látenciába burkolódzó világot.

A fentiekre figyelemmel a kutatásomban célként határoztam meg, hogy a prostituáltak szemszögéből választ kapok arra a kérdésre, hogy vajon szerintük ma Magyarországon milyen a prostituáltak társadalmi megítélése.

Hipotézisem szerint a prostituáltakat valóban kirekeszti a társadalom, annak gyakorlása ma Magyarországon az uralkodó megítélés szerint erkölcsileg elítélendő, amelyhez nagyban hozzájárul a szabályozás, és a jelenség devianciaként történő kezelése. E kérdéskörben irányadónak tekintem Lévay megfogalmazását, miszerint a kirekesztődés dinamikus, sokrétű folyamat, amelynek során az érintettek teljesen vagy részben kirekesztődnek azokból a társadalmi, gazdasági, politikai vagy kulturális lehetőségekből, szervezetekből, intézményekből, amelyek a társadalmi integrációt szolgálják. ${ }^{2} \mathrm{Ez}$ a fogalom magában foglalja a marginalizálódást, a pauperizációt, a társadalmi izolációt, a sérülékenységet és a társadalmi pozíció hiányát.

\section{Prostitúció mint deviancia}

A deviáns viselkedés szociológiájának nemzetközi irodalma áttekinthetetlenül nagy, az elmúlt 20-30 évben hazai szinten is számos kiadvány jelent meg a témáról. Elöljáróban hívnám fel a figyelmet arra, hogy ezt a hatalmas irodalmi apparátussal rendelkező tématerületet nem kívánom általános elemzés tárgyává tenni, kizárólag olyan szempontokra hívom fel a figyelmet, amelyek a prostitúció és deviancia, azaz

2 Lévay Miklós: Társadalmi kirekesztődés és bűnözés. A rendszerváltozás utáni kriminálpolitikai megközelítések Magyarországon és a társadalmi kirekesztődés. In Borbíró Andrea - Kerezsi Klára (szerk.): A kriminálpolitika és a társadalmi bünmegelözés kézikönyve I. Budapest, Igazságügyi és Rendészeti Minisztérium, 2009. 87-108. 
a választott kutatási téma és e részfejezet során hasznosak lehetnek. A devianciával kapcsolatos legáltalánosabb elméleti kérdés, hogy milyen szerepet játszik a deviancia, milyen funkciói vagy diszfunkciói vannak a devianciának a társadalomban. Ahhoz, hogy valamely jelenségnek, tettnek a normalitáshoz és az abnormalitáshoz füződő állapotát, helyzetét arányítani tudjuk, első lépésként arra a kérdésre kell választ kapnunk, hogy a szóban forgó jelenség, tett eltér-e a normálistól, és amennyiben igen, akkor vajon mennyire tér el attól. A társadalomtudományok ennek a minőségbeli mérésére használják a deviancia kifejezést. ${ }^{3}$ Köznapi gondolkodással nyilván minden deviancia kisebb vagy nagyobb mértékben károsnak, diszfunkcionálisnak látszik a társadalomra nézve. Í Igy a deviancia okaira vonatkozóan vannak biológiai, pszichológiai, közgazdaságtani és szociológiai elméletek, amelyek az egyén, a család és más elsődleges csoportok, továbbá a társadalom egészének szintjén keresik a deviancia okait. E kitekintésben a prostituáltakat nem az egyén, hanem a csoportok szintjén tehetjük vizsgálódások tárgyává. Ezeknek az elméleteknek és társadalomtudományi kutatásoknak a célját és feladatait abban látjuk, hogy a társadalom vezetése, megtervezése és prognózisa számára megfelelő elméleti alapokat és metodikai alapelveket teremtsenek. Ez feltételezi, hogy felderítsük a törvényszerű összefüggéseket, hogy időben érzékeljük az érlelődő társadalmi, politikai, kulturális stb. problémákat, és a szükséges, gyakorlati döntések kellő hatékonyságot mutassanak. ${ }^{5}$ Magyarországon Andorka, Buda és Cseh-Szombathy szerzők az 1970-es években úttörő szerepre vállalkoztak, amikor monografikus formában közreadták az erre vonatkozó legfontosabb ismereteket. ${ }^{6}$ Hazánkban az 1970-es évektől kezdődően egészen a rendszerváltásig látott napvilágot a legtöbb devianciakutatás. ${ }^{7}$ Ezeket az akkoriban hazánkban gyorsan szaporodó társadalmi jelenségeket más szóval „társadalmi normáktól elhajló” viselkedési formáknak vagy devianciának is szokták nevezni. ${ }^{8}$ Bár ez nem csak Magyarországra volt igaz, mert akkoriban minden gyorsan fejlődő és modernizálódó országban növekedtek az ilyen jellegü zavarok. ${ }^{9}$ A deviancia alapfogalmát azonban mégis Durkheimhez, a francia szociológushoz köthetjük. Durkheim rámutatott arra, hogy a deviancia nem az adott viselkedés lényegéből következik, hanem az adott társadalom ítéletéből, a társadalomban elfogadott normákból, amelyek társadalmanként és korszakonként eltérőek lehetnek. Durkheim a bűnözésnek azt a társadalmi hasznát látja, hogy alkalmat ad a közösségnek a bűnöző elítélésén keresztül arra, hogy visel-

3 Irk Ferenc: Deviancia, bün, bűncselekmény, makrokriminalitás. Jogtudományi Közlöny, 69. (2014), 4. $180-186$.

4 Andorka Rudolf: Bevezetés a szociológiába. Budapest, Osiris, 2006.

5 Cseh-Szombathy László - Ferge Zsuzsa: A szociológiai felvétel módszerei. Budapest, Közgazdasági és Jogi Könyvkiadó, 1971.

6 Andorka Rudolf - Buda Béla - Cseh-Szombathy László: A deviáns viselkedés szociológiája. Budapest, Gondolat, 1974.

7 Merényi Kálmán: Társadalmi beilleszkedési zavarok napjainkban Magyarországon. Acta Universitatis Szegediensis: Acta Juridica et Politica, 74. (2012), 321-330.

8 Enyedi György - Tamási Péter: Népbetegségeink? - A társadalmi beilleszkedési zavarok anatómiájához. Info-Társadalomtudomány, (1987), 2. 3-8.

9 Pataki Ferenc: A kutatások néhány tapasztalata. Info-Társadalomtuduomány, (1987) 2. 9-17. 
kedési normáit szimbolikusan szilárdítsa és a közösségi összetartozás érzését erősítse. ${ }^{10}$ Gönczöl megfogalmazásában a devianciák az átlagostól, az uralkodó normáktól, az elvárt és még tolerált magatartási formáktól eltérő viselkedések halmazait jelentik. ${ }^{11}$ Ez a jelenség értelmezhetetlen a társadalmi reakció nélkül, hiszen a mindenkori megítélés alapján dől el az, hogy milyen viselkedést milyen körülmények között tűrnek vagy tiltanak.

A deviáns viselkedési formák előfordulási gyakoriságának megállapítása igen bonyolult feladat. Lehetséges, hogy mind a társadalomban, mind az adott közösségben viszonylag nagyfokú tolerancia alakul ki a negatívan eltérő, akár ön-, akár közveszélyes magatartásokkal szemben, és ezek nem zavarják annak harmonikus működését. Az, hogy a társadalom milyen negatív magatartásokra reagál, mikor érzi szükségesnek az intézményes reakciót, és milyen eszközökkel kívánja végrehajtani a „szakszerü" vagy a büntető jellegű beavatkozást, sok tényező együtthatásának a függvénye. A reagálás függ a társadalmi tolerancia képességétől, a demokratikus hagyományoktól, a szaktudományok fejlettségétől és attól, hogy az általuk kínált „készletből” milyen fajta eszközöket választ ki a szakpolitika vagy a hatalmi politika. Természetesen az sem mellékes tényező, hogy a társadalom mekkora anyagi áldozatot képes és hajlandó vállalni. Az sem közömbös, hogy a munkamegosztás során az erre rendszeresített intézmények milyen eredménnyel képesek „kezelni” a negatív jelenségeket, úrrá tudnak-e lenni a kialakult, esetleg már nehezen tolerált helyzeten, valamint, hogy maguk mennyiben járulnak hozzá a devianciák újratermelődéséhez. Ebben az értelemben akkor anómiás egy társadalom, ha a közösség már jelentős politikai kérdésnek tekinti az ön- és közveszélyes magatartások okozta fenyegetettséget, és azt észleli, hogy az erre rendelt és működtetett intézmények nem képesek megfelelő hatékonysággal biztosítani a közbékét és a köznyugalmat. Durkheim értelmezése szerint az anómia nem más, mint a társadalmi rend felbomlása, amelyben az értékek és a normák elvesznek, illetőleg az az állapot, amikor egy társadalmi gyakorlat eltér a társadalom által vallott normáktól. Durkheim szerint a gyors gazdasági és társadalmi változások, legyen az válság vagy fellendülés, anómiás állapothoz vezet. Ilyen helyzetben az emberek elvesznek a társadalomban, és gyakran reagálnak deviáns viselkedéssel, például bünözéssel. ${ }^{12}$ Merton viszont az anómia kialakulásának okaként nem a gyors társadalmi változásokat nevezte meg, hanem az olyan társadalmi szerkezetet, ami ugyanazokat a célokat tủzi ki a társadalom minden tagja elé, anélkül hogy egyenlő eszközöket biztosítana a cél elérése érdekében. Merton szerint két tényező fontos a társadalomban: A kulturális törekvések és célok (jólét, siker, státusz), valamint a célok eléréséhez szükséges intézményesített eszközök (tanulás, munka, takarékosság). Sokak számára

10 Émile Durkheim: A társadalmi tények magyarázata. Budapest, Közgazdasági és Jogi Könyvkiadó. 1978.

11 Gönczöl Katalin: A bűnözés kontrollja: kriminálpolitika. In Gönczöl Katalin - Kerezsi Klára - Lévay Miklós (szerk.): Kriminológia. Budapest, Wolters Kluwer, 2019. 117.

12 Durkheim i. m. (10. lj.) 
viszont ezek a célok elérhetetlenek, ezért más megoldásokat keresnek, amely főként a bűnözésben nyilvánul meg. ${ }^{13}$

Gönczöl is megerősíti, hogy a deviáns viselkedési formák nem egyformán érintik a társadalmi rétegeket, megoszlásuk általában egyenetlen. A társadalmi periférián a deviáns magatartások szinte minden formája halmozottan fordul elö. ${ }^{14}$ Elképzelhető ugyan, hogy magas a deviáns magatartások száma, de azok többnyire a társadalom viszonylag szűk, zárt rétegeiben fordulnak elő, és addig, amíg a mértékadó köröket nem veszélyeztetik, nem válnak politikai tényezővé, és így nem váltják ki a kontrollmechanizmus intenzívebb müködését. ${ }^{15}$

Halmozottan igaz ez a prostitúció kérdéskörében is, hiszen minden egyes korban a társadalmi tolerancia képességének relációjában az adott társadalmi hatalom döntötte el, hogy hogyan kívánja a prostitúció jelenségét kezelni, vagyis, hogy a kérdéskör rendezésére az adott hatalmi politika milyen eszközöket választ: ha tiltani kívánta - mert a társadalom annak gyakorlását ellenezte, és üldöztetését kívánta -, akkor a prohibíció eszköztárával lépett fel. Ha mint „szükséges rosszat” eltürte - mert a társadalom rosszalló értékítélete mellett a hatalom annak gyakorlására is lehetőséget kívánt biztosítani -, akkor reglementációs intézkedéseket vezetett be, és ha a reintegráció/reszocializáció került előtérbe - azaz a társadalom szolidaritását és együttérzését fejezte ki az áldozati status quo mellett -, akkor abolícionista szemléletet alkalmazott. Bármelyiket is vesszük alapul, a prostitúció jelenségét még a legerősebb büntetőjogi üldöztetés, szabályozás és a szabályozás ellen fellépő modell sem tudta megszüntetni. ${ }^{16} \mathrm{~A}$ tiltó és reglementáló intézkedésekkel az államhatalom éppúgy hozzájárult a társadalmi kirekesztéshez, mint például a megbélyegzéssel vagy az előítélettel maga az egyének csoportja, azaz a társadalom. Ennek miértjeit a hatályos szabályozásban kell keresnünk.

Magyarország 1955. szeptember 29-én az Egyesült Nemzetek Főtitkáránál letette nyilatkozatát, miszerint csatlakozni kíván az 1950. március 21-én New Yorkban Az emberkereskedés és mások prostitúciója kihasználásának elnyomása tárgyában született nemzetközi egyezményhez (Egyezmény). Magyarország az 1955-ös évben kihirdetett 34. törvényerejü rendelettel csatlakozott az Egyezményhez, az abban foglaltakat önmagára nézve kötelezőnek ismerte el. A csatlakozás időpontjában még hatályos volt az 1955. évi 17. törvényerejü rendelet, amely az üzletszerü kéjelgés sui generis bűncselekményi tényállását mint önálló bủncselekményt büntetni rendelte. Ez azt jelentette, hogy a hivatkozott norma éles ellentétben állt a „prostituáltbarát-

13 Robert K. Merton: Középszintű szociológiai elméletek. In Robert K. Merton K. (szerk.): Társadalomelmélet és társadalmi struktúra. Budapest, Gondolat, 1980. 83-141.

14 Gönczöl Katalin: Devianciák, devianciakontroll, bűnmegelőzési stratégiák. In Gönczöl Katalin - Korinek László - Lévai Miklós: Kriminológiai ismeretek, bünözés, bünözéskontroll. Budapest, Corvina, 1996. 119-134.

15 Balogh Sándor - Pallagi Anikó: A deviancia, az egyes deviáns magatartások. Budapest, Rendőrtiszti Főiskola, Rendvédelmi füzetek, (2001), 47. 1-20. 1-16.

16 Kovács István: Egy empirikus kutatás részletei: a prostitúció jelensége és társadalmi kontrollja napjainkban. Budapest, Dialóg Campus, 2019b. 1-248. 
nak" tekinthető nemzetközi egyezménnyel, hisz az a prostituáltak áldozati jellegét hirdeti, és azokat rendeli büntetni, akik a prostitúcióból élősködő jelleggel hasznot húznak. A konvenció még ma is hatályos, és az aláíró országok számára meghatározó támpontnak kellene lennie a jogalkotásban, viszont Magyarország tekintetében sajnálatos módon még napjainkban is számos azzal ellentétes intézkedés lát napvilágot, és maradnak használatosak a kezelés gyakorlatában. Nagyon jó példa erre, hogy egészen 1993-ig kellett várni, míg az 1993. évi XVII. törvény hatályon kívül helyezte az 1955. évi 17. törvényerejű rendeletet, azonban az állam a prostituáltak büntethetőségéről nem mondott le. A szabálysértési törvény bevezetésével, és annak keretrendelkezésével ugyanis a prostituált - a közrendvédelmi, gazdasági vagy közegészségügyi rendelkezések megszegése esetén - szankcionálható, a társadalomra kisebb fokban veszélyes magatartás miatt büntethetö, azaz továbbra is bủnelkövetőként aposztrofálható. Az 1948-ban született Emberi Jogok Egyetemes Nyilatkozata (Nyilatkozat) meghatározza azokat a fó alapelveket, amelyek a későbbi egyezményeket, így például a New York-i konvenciót is megalapozzák. Az Alapokmányban a tagállamok kötelezik magukat arra, hogy az ENSZ szervezetével együttmüködve biztosítsák az emberi jogok és az alapvető szabadságok tiszteletben tartását. Ahogy a Nyilatkozat 28. cikkelye kimondja: „Minden személynek joga van ahhoz, hogy mind a társadalmi, mind a nemzetközi viszonyok tekintetében olyan rendszer uralkodjék, amelyben a jelen Nyilatkozatban kinyilvánított jogok és szabadságok teljes hatállyal érvényesülhessenek." Azáltal, hogy a prostituáltat a nemzetközi jog áldozatnak, a magyar szabályozás pedig bủnelkövetőnek tekinti, a joggyakorlás tekintetében olyan mély szakadékot képez, amely hozzájárul a prostituáltak elszigetelődéséhez. A társadalomban a hatóság felel a jogok gyakorlásának és kötelmek teljesítésének biztonságáért, azonban ez az ambivalens helyzet tovább mélyítheti a szakadékot.

Az egyezmény hatálybalépése óta 70 év telt el és ez idő alatt nem történt módosítás vagy kiegészítés. Az összegyüjtött szakirodalomban a kirekesztés három nagyobb okáról olvashatunk: biológiai degeneráció, betegségek hordozása és bűnözés.

\section{Prostitúció és deviancia}

A prostituáltakra a társadalom úgy tekint, mint a betegségek hordozóira, a köz szégyenére, ez büntethetőségük alapja is egyben. ${ }^{17}$

A közelmúltban a prostitúció eredetének magyarázatát a biológiai degenerációban és parazitizmusban jelölték meg. Legismertebb képviselöje Cesare Lombroso volt, akinek munkásságára nagy hatást gyakoroltak az olyan tudományok, mint a frenológia. 1876-ban jelentette meg L’uomo delinquente (A bűnöző ember) címü könyvét, amely új fejezetet nyitott mind a kriminológiában, mind az orvostudományban, a „született bünöző" és a „született prostituált” definíciójának megalkotásával. ${ }^{18}$ A megbélyegzés

17 Bódis Enikő: Prostituált narratívák. In Fehér Lenke (szerk.): Adás-vétel - konferencia a prostitúcióról. Budapest, Országos Kriminológiai Intézet. 2011, 14-20.

18 Cesare Lombroso: L'uomo delinquente. Milan, Hoepli, 1876. 
középpontjában a biológiai hajlam állt. A prostituált már úgy jön a világra, hogy születéskor magával hozza azt a hajlamot, amely később a prostitúcióba hajtja. ${ }^{19}$ „A körülmények csak másodlagos hajtóerők, legerősebben a hajlam uralkodik.” ${ }^{20}$ A korban elvégzett antropometriai kutatási módszerek azonban hiányosnak mutatkoztak, eredményeikre alapozott állításaik sorra dőltek meg. ${ }^{21}$ Lombroso például nem végzett szigorú statisztikai összehasonlító vizsgálatokat, elméletét előszőr Buckman majd további szerzők sorra cáfolták..$^{22}$ A „biológiai” szemléletet a „racionális döntéselmélet”, valamint a „rutintevékenység-megközelítés” és a „csekély önkontroll” elmélet is cáfolja. ${ }^{23}$ Joggal hihetnénk, hogy a társadalmi fejlődés következtében a „biológiai” szemlélet a 21. században megszűnt, azonban még mindig vannak olyan szerzők, akik e tradíciókat tovább táplálják. Farley a prostitúció jelenségét erkölcsi tébolynak tartja, a született prostituáltak meghatározó jellemzőjét különféle személyiségzavarokban jelöli meg. ${ }^{24}$ Forrai 2011-ben cáfolta ezt az elméletet, és kimutatta, hogy a személyiségzavarok a prostitúciónak nem kiváltó okai, hanem annak következményei. ${ }^{25}$ A Nyilatkozat 1. cikkelye kimondja: „Minden. emberi lény szabadon születik és egyenlő méltósága és joga van. Az emberek, ésszel és lelkiismerettel bírván, egymással szemben testvéri szellemben kell hogy viseltessenek." Azzal, hogy a prostituáltakat megbélyegzik, „eleve elrendeltetettek", így az egyenlő bánásmód, az emberi méltóság és a szabadon való születés alapelvei sérülhetnek, kerülhetnek veszélybe. A Nyilatkozat 2. cikkelye kimondja: „Mindenki, bármely megkülönböztetésre, nevezetesen fajra, színre, nemre, nyelvre, vallásra, politikai vagy bármely más véleményre, nemzeti vagy társadalmi eredetre, vagyonra, születésre vagy bármely más körülményre való tekintet nélkül hivatkozhat a jelen Nyilatkozatban kinyilvánított összes jogokra és szabadságokra." A stigmák ezt az alapelvet éppúgy sérthetik azáltal, hogy a prostituáltakat születésüknél fogva megkülönböztetik.

A társadalom a prostituáltakat gyakorta a bủnözéssel köti össze, amely a társadalmi kirekesztettség egyik centrumának is tekinthető. Veszélyességük mindenekelőtt a bűnözéssel fennálló kapcsolatában és kölcsönhatásában, a bűnözéstől távol álló erkölcsi rétegek züllesztésében mutatkozik. ${ }^{26} \mathrm{Az}$ önálló tettesek jellemzője, hogy az éjszakai életben rendszeresen megfordulnak, tevékenységük nagyfokú szervezettségre utal, a bünözést fö foglalkozásnak tekintik, amely a nemzetközi élvonalba is bekapcsolódik. A társtettesek a büncselekmény elkövetéséhez szükséges pszichikai

19 Otto Weininger: Anyaság és prostitúció. Budapesti Negyed, 18. (2010), 3. 385-391.

20 Tartsányi Miklós: Falusi lány Pesten. Csendőrségi Lapok, 34. (1944), 14. 6-10. 8.

21 Hortobágyi Richárd: Prostitúció egy ipari nagyvárosban. Belügyi Szemle, 9. (1971), 5. 120-121.

22 Charles G.Buckman: The English Convict. A Statistical Study. Virginia, General Books, 2010.

23 Farkas Zoltán: A racionális cselekvés, társadalmi cselekvés és kölcsönhatás. Társadalomelmélet 5. Miskolci Egyetem, 2006.

24 Melissa Farley: Prostitution and the Invisibility of Harm. Women \& Therapy, 26. (2003), 3-4. 247-280.

25 Forrai Judit: Prostituáltak mentális problémáinak elmélete és különböző tények feltárásának kezdetei a 19. században. Magyar Onkológia, 55. (2011), 3. 222-223.

26 Bodor Endre - Szücs János: A prostitúció helyzete a fővárosban. Belügyi Szemle, 2. (1964), 6. 27-34. 
és/vagy fizikai segítséget nyújtanak. Leginkább vagyon elleni büncselekményeket követnek el. ${ }^{27}$

A prostituáltak életét társadalmi megbélyegzés (erkölcstelenség, bünözés) övezi, viselkedésük ettől válik devianciává. A rendőri devianciaelméletek ${ }^{28}$ bukását saját embereik idézték elő. Ennek részleteit több tanulmányban is olvashatjuk: a prostitúció kezeléséhez szükséges intézkedéseket - különösen az áldozatvédelem területén - nem sikerült megvalósítani. ${ }^{29}$ Illúziót kergetünk, ha azt hisszük, hogy a rendőri erőszak fokozása tartós eredményt hozhat. A prostitúció súlyos társadalmi, de leginkább gazdasági okokból eredő jelensége ilyen kriminálpolitikai eszközök alkalmazásával nem szabályozható. ${ }^{30} \mathrm{~A}$ hatóságok megtorló intézkedései nem segítenek, azoknak csak káros hatásaik vannak. ${ }^{31}$ A Nyilatkozat 7. cikkelye kimondja: „A törvény előtt mindenki egyenlő és minden megkülönböztetés nélkül joga van a törvény egyenlő védelméhez." A Nyilatkozat 10. cikkelye kimondja: „Minden személynek teljesen egyenlő joga van arra, hogy ügyét független és pártatlan bíróság méltányosan és nyilvánosan tárgyalja, $\mathrm{s}$ ez határozzon egyrészt jogai és kötelezettségei felől, másrészt minden ellene emelt bünügyi vád megalapozottsága felől” A Nyilatkozat 11. cikkelye kimondja: „Minden büntetendő cselekménnyel vádolt személyt ártatlannak kell vélelmezni mindaddig, amíg bűnösségét nyilvánosan lefolytatott perben, a védelméhez szükséges valamenynyi biztosíték mellett, törvényesen megállapítják." Azáltal, hogy a prostituáltat kezdetektől fogva bűnelkövetőnek tekintik az Egyezmény hetes, tízes és tizenegyes cikkelye is veszélybe kerülhet, az abban tárgyalt alapvető jogok érvényesülése csorbulhat. A hatóságok és a prostituáltak közötti szakadék - mind az ügyintézés, mind az intézkedések, mind az eljárások tekintetében - ezáltal tovább mélyülhet, a kirekesztettség tovább erősödhet.

Talán az egyik legnagyobb stigma, amelyet a társadalom a prostituáltakra vetített, az a nemi betegségek terjesztése volt. Ennek első írásos bizonyítéka 1863-ból való, amikor is Grosz Lajos az Orvosi Rendőrség címü könyvében megállapította, hogy a nemi betegségek terjesztésének felelősei egyértelmüen a prostituáltak, akiknek fertőzöttségét legalább egy héten kétszer ellenőrizni kell; a már megbetegedett nőket pedig zárt osztályon szükséges kezelni. ${ }^{32}$ Míg a dualizmusban a gonorrhoea állt a középpontban, addig a rendszerváltás után az AIDS/HIV-fertőzés. ${ }^{33} \mathrm{~A}$ kábítószerhasználat, a védekezés nélküli nemi együttlét, a higiéniás környezet hiánya stb. mind-

27 Farkas Zoltán - Lombos Lajos: A prostitúció elleni intézkedések. Rendörségi Szemle, 5. (1957), 10. $672-680$.

28 A bűnözés és a prostitúció összefüggéséből adódó saját meghatározás.

29 Juhász Géza: Hogyan hátráltatja a nőkereskedelem felszámolását a nők emberi jogai iránt érzéketlen magyar büntetöjogi szemlélet? Budapest, Habeas Corpus Munkacsoport, 2004.

30 Borai Ákos: Prostitúció. Kecskemét, Print 2000 Nyomda Kft., 2003.

31 Molnár Lajos: Az erkölcsök, a közegészség és a prostitúció. Budapesti Negyed, 18. (2010), 3. 67-101.

32 Forrai Judit: Visszatekintés a budapesti prostitúció múltjára. Belügyi Szemle, 45. (1997), 5. 105-119.

33 Michael D. Smith - Christian Grov - David W. Seal - Peter McCall: A Social-Cognitive Analysis of How Young Men Become Involved in Male Escorting. The Journal of Sex Research, 50. (2013), 1. 1-10. 
mind indoka a betegségek elterjedésének és terjesztésének. ${ }^{34}$ Egyoldalúan kijelenteni, hogy a nemi betegségek terjesztéséért a prostituáltak a felelősek, nem lehet. Nagyon sok prostituált nő a nemi betegségeket többek között futtatójától, és/vagy ügyfelétől kapja el. ${ }^{35}$ De ugyanilyen bizonyíték áll rendelkezésre a tekintetben is, hogy nemcsak az óvszerhasználat nélküli, hanem az önhibán kívüli - következetlenül és helytelenül alkalmazott - óvszerhasználat is növeli a nemi betegségek terjedésének kockázatát. A prostituáltak nagy része arról számolt be, hogy nehéz az ügyfeleket meggyőzni arról, hogy óvszert alkalmazzanak, amennyiben ellenvetéssel élnek, úgy a kliensek agreszszív, heves reakcióival szembesülnek, megfélemlítik őket. ${ }^{36}$ Megjegyzendő, hogy egy friss kutatás rávilágított, hogy a HIV vírus terjesztésében a férfiak igencsak közremüködnek. A prostituáltakhoz járó férfiak feleségeiket, szexuális partnereiket és alkalmi áldozataikat is megfertőzik. Következésképpen a fertőzéseket a nők és lányok a férfiaktól kapják meg. ${ }^{37} \mathrm{~A}$ fentiek szintén alááshatják a korábban már taglalt Nyilatkozat 1. és 2. cikkét, amely az egyenlő bánásmód, az emberi méltóság alapjogok gyakorlását sodorhatják veszélybe.

A forráselemzést követően a következő részben bemutatom, hogy a 21. században a prostituáltak hogyan vélekednek a devianciáról, és a velük szemben fennálló marginalizálódásról és társadalmi kirekesztettségről.

\section{Tudományos módszertan}

A tudományos módszertan, így a felmérés gerincét a kvantitatív módszeren alapuló anonim „survey” metódus alkotta. Nehéz dolga van a kutatónak, amikor egy olyan jelenséget szeretne tanulmányozni, amely egyébként is látenciába burkolódzik, maga körül pedig egy olyan betekintést nem türő, elzárkózó világot teremt, ahol a belépést az illetéktelenektől megtagadják.

Első lépés a minta kiválasztása volt. A minta kiválasztása nagyban függött a populáció nagyságától, homogenitásától, a mintaadatoktól, a használat költségétől, és a szükséges hiteles és pontos adatelemzés és értékelés mértékétől. A minta kiválasztásának előfeltétele volt, hogy az a célpopuláción belül a lehető legszűkebb legyen. (Például, aki korábban prostituáltként dolgozott, de jelenleg más munkakörben dolgozik, és ezen életmóddal szakított, a felmérés alanyául nem szolgálhat.) Ugyanakkor

34 Edward V. Morse - Patricia M. Simon - Howard J. Osofsky - Paul M. Balson - H. Richard Gaumer: The male street prostitute: A vector for transmission of HIV infection into the heterosexual world. Social Science and Medicine, 32. (1991), 5. 535-539.

35 Gunilla Ekberg: Nemzetközi vita a prostitúcióról és nőkereskedelemről: az érvek cáfolata. In Forgács Zsuzsa és Juhász Géza (szerk.): Szeminárium a prostitúció törvényesitésének hatásairól. Budapest, 2004, 1-70.

36 Richter, Marlise: Sex work, reform initiatives and HIV, AIDS in inner city Johannesburg. African Journal of AIDS Research, 7. (2008), 3. 323-333. D. Nairne: We want the power: Findings from focus group discussions in Hillbrow, Johannesburg. Research for Sex Work, (2000), 3. 3-5.

37 H. P. Hynes - C. Raymond: Put in harm's way: the health consequences of sex trafficking in the United States. In J. Silliman - A. Bhattacharjee (szerk.): Policing the national body: Sex, race, and criminalization. Cambridge, MA, South End, 2002. 197-229. 
a minta kiválasztásában a véletlenszerúség fontos szerephez jutott. Nagyon kiterjedt, konspiráción alapuló kapcsolati háló szükséges ahhoz, hogy akár a kutató, akár más e körbe bekerülhessen, onnan információt szerezzen, és azt ráadásul még fel is használhassa.

A kutatást - a jelenség látenciájából adódóan - rejtett és nehezen elérhető populációk (a prostituáltak) körében végeztem, ezért a minta kiválasztásánál a nehezen elérhető populációhoz használt, úgynevezett hólabda- (snowball-) módszert alkalmaztam. A hólabdamódszer alkalmazása jelen esetben lényegében nem jelentett mást, minthogy amikor a személyes kapcsolatrendszeremen keresztül (prostituáltak, rendőrök, „éjszakai” emberek stb.) a rendelkezésre álló felmérés alanyai elfogytak (telefon, személyes látogatás, levelezés, chatelés stb.), a már megkérdezett személyektől (azok véletlenszerü/tudatos kiválasztásával) kértem segítséget arra, hogy további válaszadó személyek felkutatásában (annak kapcsolatai révén, barátaival, ismerőseivel, munkatársaival, kollégáival majd azok ismerőseivel, munkatársaival, kollégáival, barátaival) segítséget nyújtsanak. Ezt az eljárást addig folytattam, amíg a minta tervezett számát el nem értem.

A minta kiválasztásánál kiemelt hangsúlyt fektettem arra, hogy a Nemzetközi Szociológiai Társaság által kiadott Etikai Kódexben foglaltak érvényesülését garantáljam, azokat magamra nézve kötelező érvényűnek ismerjem el. Kérdőíves vizsgálatoknál vagy mélyinterjúknál is fontos, hogy a válaszadás önkéntes és az adatszolgáltatás anonim legyen. Minderre külön figyelmet fordítottam, így különösen arra, hogy a kérdőíveket kizárólag önkéntes vállalás és hozzájárulás alapján töltsék ki, és már a kitöltés pillanatában anonimek voltak, hiszen a személyekről semmilyen azonosítható adat nem állt rendelkezésemre. A kérdőíveket kódolásuk után megsemmisítettem, a válaszadók utólagos azonosítására alkalmas adatokat nem tároltam, és a megkérdezetteket tájékoztattam arról, hogy az eredményeket mire fogom felhasználni.

A minta méretét öt tényező befolyásolta: a kívánt pontosság és a felmérés nehézségi foka, a statisztikai teljesítmény, a kutatói képességem, hogy a felmérés alanyaihoz hozzáférhessek, és a releváns információkat biztosító értékelő, elemző munka kiválasztása. A fentiek figyelembevételével összességében 100 fő sikeresen töltötte ki a kérdőíveket.

A felmérés összeállítása során nyitott és zárt láncú kérdésekre kellett válaszolni. A nyitott kérdések lehetővé tették a válaszadók számára, hogy saját szavaikkal válaszolhassanak, azonban olykor-olykor annak elolvasása (amennyiben azt folyóírással töltötték ki) megpróbáltató feladatnak ígérkezett. A nyitott kérdésekre vonatkozó válaszadás remek lehetőséget adott arra, hogy olyan véleményeket ismerjek meg, amelyek irányított válaszok, és a kérdéseken túlmenően a felmérés alanyainak megélt tapasztalatán keresztül mutatkozik meg. Mivel a nyitott kérdéseknél a válaszadó részéről a válaszadás időigényesebb, ezért sokkal megfontoltabb, önálló, saját gondolatokat tartalmazó véleményalkotásra alkalmas válasz is születhet. A zárt végü kérdések során a válaszadók a megadott válaszok közül választhattak. A felmérés alanyai az előre megadott válaszok közül dönthetik el, hogy a saját, megélt tapasztalataikhoz melyik 
válasz milyen közel áll. A zárt kérdések megalkotásakor a numerikus, azaz a Likertskála szerinti, valamint a rendezetlen válaszadás szerinti kérdésfeltevés módszerét és válaszadás lehetőségeit vonultattam fel. A numerikus válaszadás egy skálázó értékrendszer alapján kérte a válaszadót, hogy azok között az általa meghatározott sorrend felállítását követően döntsön, míg a rendezetlen válaszadásra épülő értékrendszer arra kérte a válaszadót, hogy a válaszok összehasonlítását követően, annak általa ítélt legjellemzőbbre tekintettel az állításokat kiválassza. Számomra fontos feladatnak ígérkezett, hogy biztosítsam, hogy a válaszadás lehetősége ne egy válaszra korlátozódjon, több alternatíva álljon rendelkezésre. A kettő közötti átmenet lehetőségét biztosította a részleges zárt végü kérdések megválaszolása, amelynek során a lehetséges válaszok megadása mellett, az „egyéb” és/vagy „más” lehetőségek a kört bővítették.

A kérdőívek összeállítását és kitöltetését követően azokat egy nagy adatbázisban összesítettem, majd megkezdődhettek a matematikai statisztikai számítások. Mindezekhez a statisztika segítségével kvantitatív eljárás keretén belül különböző függvények beágyazásával minimumot, maximumot, átlagot, móduszt és szórást számítottam. Az alapstatisztikai számítások alapján kapott eredményeket pedig olyan összehasonlító kvantitatív eljárás fogta össze, amely a gyakoriságok közötti korrelációs koefficiens értékét a Cohan-féle általános skálán illusztrálni tudta. ${ }^{38}$

A kutatás reprezentatívsága vonatkozásában elmondható, hogy az a prostituáltak tekintetében objektíven nem eldönthető, mivel az 1/2011. (I. 14.) számú AB határozat értelmében a hatóság a prostituáltakat nyilvántartásba nem veheti, így személyre bontott, mennyiségileg regisztrált számadat rendelkezésre nem áll. Az integrált ügyviteli és ügykezelő rendszerben (rendőrségi rendszer) is csak olyan adatok állnak rendelkezésre, amelyek a már eljárás alá vont prostituáltak adatait tartalmazzák, azonban az, létszámukról teljes képet szintén nem ad. Becslések állnak rendelkezésre, amelyek szintén nem egzakt számokon alapulnak. A 100 személyből álló mintáról viszont elmondható, hogy a Magyarországon müködő prostitúciós hálózat társadalmi szerkezetének teljes mértékben megfelel, a főbb bázispontok, az alá-fölé rendeltségi viszonyok, a helyszínek, a személyek stb. mind-mind a tényleges valóságot tükrözik.

\section{Eredmények}

\subsection{Személyes körülmények}

A személyes körülmények 8 kérdést tartalmazott: életkor, nemi identitás, tanulmányi végzettség, családi állapot, kedvezményezettek száma, havi jövedelem, születési hely, lakhely és/vagy tartózkodási hely vonatkozásában. Ez összesen $2 \mathrm{db}$ nyílt, 3 db zárt (azon belül is, $0 \mathrm{db}$ numerikus, $3 \mathrm{db}$ rendezetlen) és $3 \mathrm{db}$ részlegesen zárt végü kérdést ölelt fel. A tanulmányban vizsgált hipotézis szempontjából azonban csak az életkor, a nemi identitás bírt jelentőséggel, ezért csak azok ismertetésére kerül sor.

38 Jacob Cohen: The earth is round ( $\mathrm{p}<.05)$. American Psychologist, 49. (1994), 12. 997-1003. 


\subsection{1. Életkor}

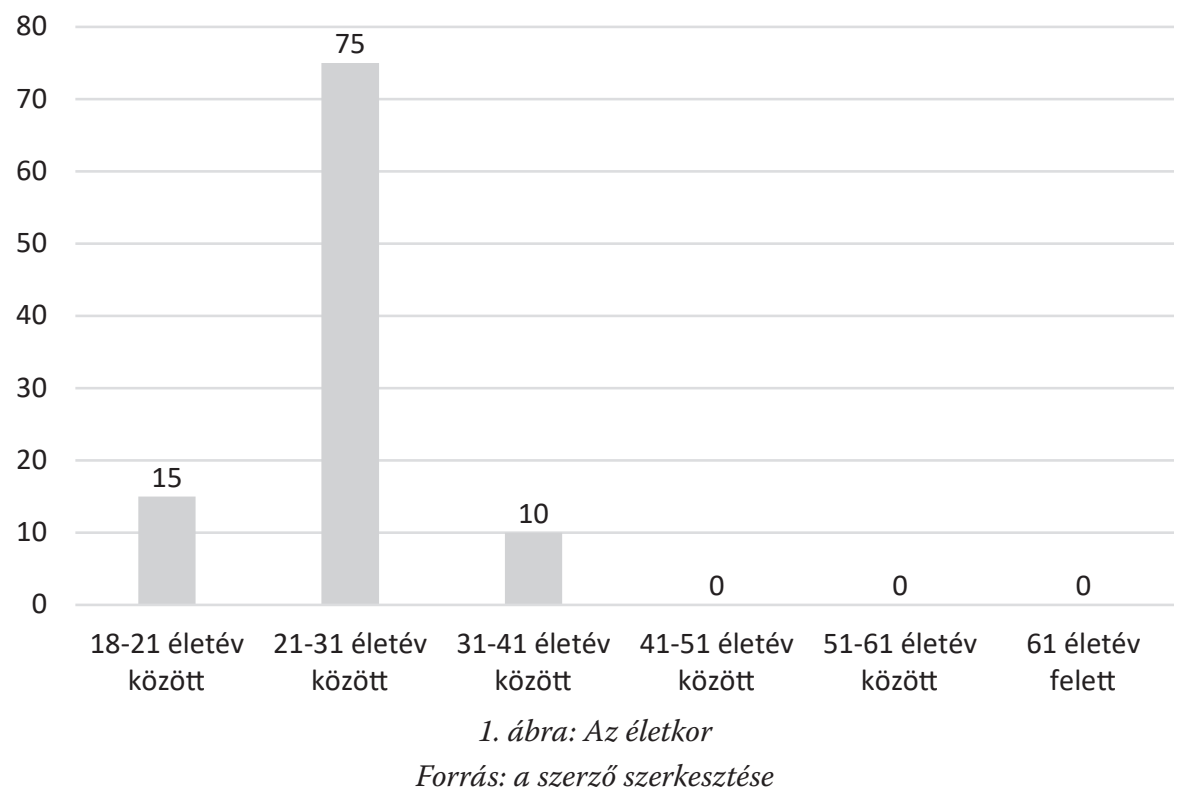

A feltett kérdés a résztvevő személyes életkorának megismerésére irányult. (A résztvevőnek a felsorolt kategóriák közül azt kellett kiválasztania, amely kategória szerinti intervallumba az életkora beletartozott.) A kérdőív összeállítása során 6 csoportot különböztettem meg: prostituáltak 18-21 életév, 21-31 életév, 31-41 életév, 41-51 életév, 51-61 életév között, valamint 61 év felett. A megkérdezettek közül 15 fő magát 18-21 életév közöttinek, 10 fő magát 31-41 életév közöttinek és (a legtöbben) 75 fö magát 21-31 életév közöttinek vallotta. A többi életkori kategóriából személy nem volt. A minimumérték 10, a maximumérték pedig 75 volt. Átlagérték-számításra lehetőség nem volt, mert az életkor skálázó értéket képviselt, így konkrét számtani értéket nem határoztam meg.

\subsubsection{Nemi identitás}

A feltett kérdés a résztvevő társadalmi nemének meghatározására vonatkozott. (A résztvevőnek a felsorolt kategóriák közül azt kellett kiválasztania, amely jelenleg a társadalmi nemét jellemezte. Függetlenül attól, hogy születéskor milyen nemüként sorolták be.) 3 csoportot különböztettem meg. Férfi, nö, transznemü. Az ember születéskor megállapított neme (férfi vagy nő) fizikai jellemzőin alapul. Ez azonban olykor nincs összhangban az adott személy nemi identitásával - azaz azzal, ahogyan a neméhez viszonyul és a nemére gondol. Mivel egyre több transzszemély nyíltan elutasítja, hogy férfiként vagy nőként azonosítsák, egyértelművé válik, hogy a nemhez való 
viszony nem szorítható be szük „női” vagy „férfi” skatulyába. A kérdőív kialakításakor minderre, valamint az Európai Unió Alapjogi Chartájának 1., 2., 3., 8. és leginkább 21. pontjaira (jog az emberi méltósághoz; jog az élethez; jog a személyi sérthetetlenséghez; jog a magán- és a családi élet tiszteletben tartásához; jog a megkülönböztetéstől, többek között a nem alapján történő megkülönböztetéstől való mentességhez) tekintettel férfi, nő, transznemủ kategóriákat képeztem. A felmérésben részt vevők legtöbbje 93 fö, azaz a megkérdezettek 93\%-a (a maximum értéket képviselve) nőnek, míg 5 fö, azaz 5\% férfinek, 2 fő (2\%) transzneműnek vallotta magát. A minimumértéket és ezzel a felmérésben részt vevők legkisebb létszámát a transzszexuálisok alkották, akik 2 fóvel, azaz 2\%-kal képviseltették magukat.

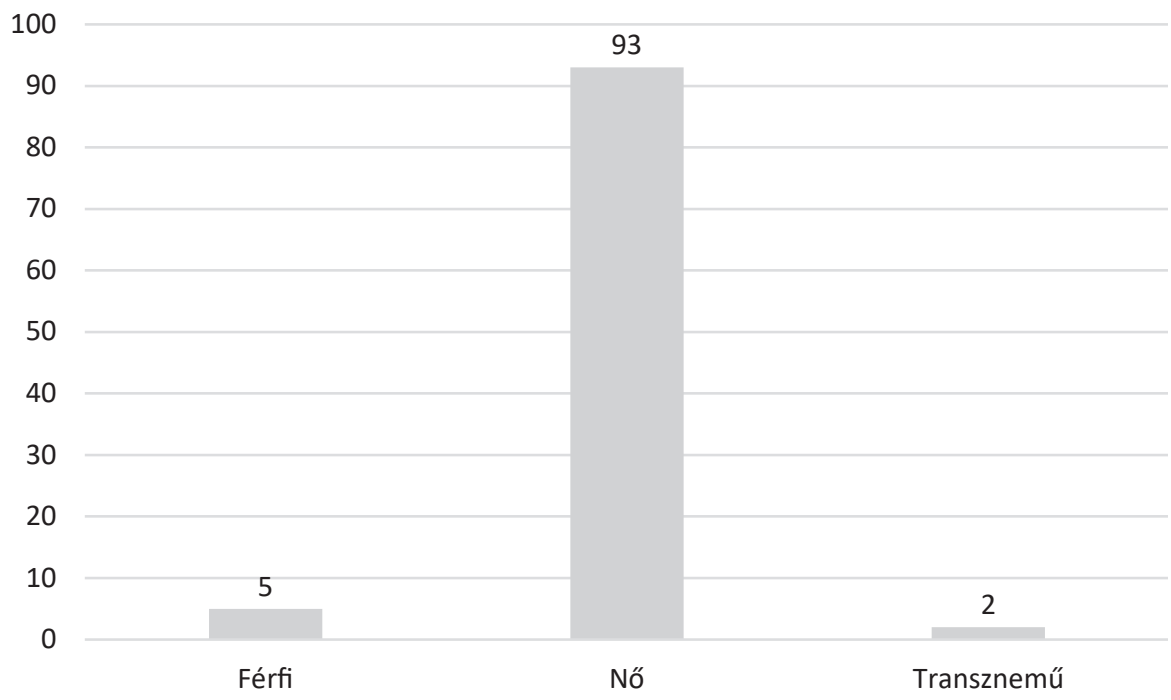

2. ábra: Nemi identitás

Forrás: a szerző szerkesztése

\subsection{A prostitúció jelensége}

A kutatás második témaköre a prostitúció jelenségével kapcsolatos attitűdök megismerését biztosítja. A fejezet 20 kérdést tartalmazott: a prostitúció fogalma, szabályozása, megítélése, a moralitás, a moralitás személyei, a munkavégzés helyszíne, autonómiája, kezdete, időtartama, minősége, intenzitása, időtartama, típusa, a munkavégzés típusának korlátozottsága, az összeg, a prostitúció mint munka megítélése, a kilépés lehetősége, a munkatársak viszonya és a munkakörnyezet. A fejezet összesen $0 \mathrm{db}$ nyílt, $19 \mathrm{db}$ zárt (azon belül is, $7 \mathrm{db}$ numerikus, $12 \mathrm{db}$ rendezetlen) és $1 \mathrm{db}$ részlegesen zárt végủ kérdést tartalmazott. A tanulmányban azonban kizárólag a moralitásról, a moralitás személyeiről és a prostitúció megítéléséről alkotott nézőpontot és annak eredményeit ismertetem. 


\subsubsection{Moralitás}

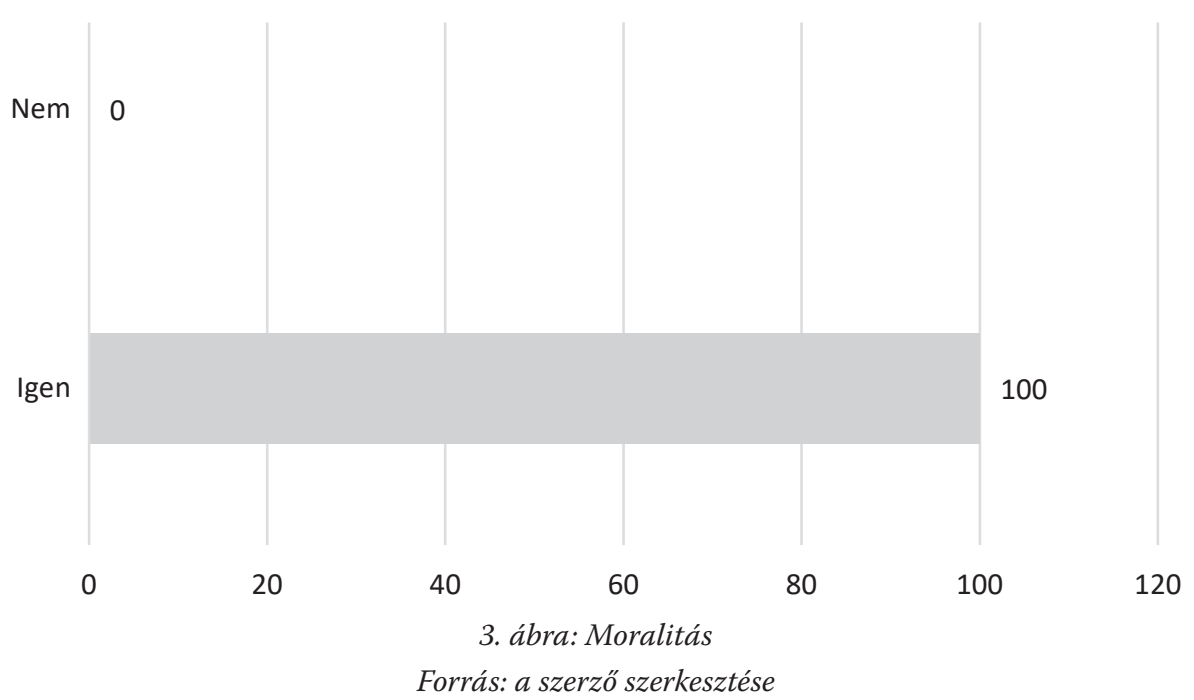

A feltett kérdés annak megválaszolására irányult, hogy a résztvevők szerint problémát jelent-e a társadalom számára országában a prostitúció jelensége? (A felsorolt válaszok közül a résztvevőnek azt kellett kiválasztania, amely megítélése szerint az országára jellemző.) 2 kategóriát állítottam fel: „igen; nem”. A válaszadók egyöntetűen kinyilvánították véleményüket, amikor mindannyian, 100\%-ban a feltett kérdésre igenlő választ adtak. A felmérésben részt vevők álláspontja szerint ma Magyarországon a prostitúció jelensége problémát keletkeztet, ezért az abban részt vevők, így különösen a prostituáltak, marginalizált csoporttá lépnek elő, társadalmi perifériára sodródnak. Ebből adódóan elesnek a reintegráció lehetőségétől, a társadalom kirekeszti őket. Mivel a válaszadók mindegyike igenlő választ adott, ezért nincs szükség a statisztikai adatok további elemzésére. A maximumérték 100 volt.

\subsubsection{Moralitás személyei}

A feltett kérdés hipotetikus volt: akkor válaszolhatták meg a felmérésben részt vevők, ha az előző kérdésre igenlő választ adtak. A fentiekre tekintettel a résztvevőknek az alábbi listából a moralitás személyét és/vagy személyeit volt szükséges kiválasztania. (A felsorolt válaszok közül a résztvevőnek azt kellett kiválasztania, hogy ki a leginkább jellemző személy, és/vagy személy, aki részéről úgy gondolja, hogy a prostitúció problémát jelent. A felsorolásból több kategória is kiválasztható volt.) Öt kategóriát állítottam fel: „leginkább a jogalkotónak; leginkább a rendvédelmi szerveknek; leginkább a civileknek; leginkább a multivállalatoknak; mindegyiknek, de nem az ügyféli körhöz tartozóknak". A válaszadók legtöbbje nem differenciált a kategóriák között, úgy gondolták, hogy a prostitúció álalános rossz, deviáns a társadalomban. A jelenség 
ebből adódóan mindenkit zavar, aki nem az ügyféli körhöz tartozik. Ad absurdum, a válaszadók $71 \%$-a (71 fó) egyértelműsítette azt, hogy aki nem vesz igénybe prostitúciós szolgáltatást, az problémaként tekint a prostitúció jelenségére, amely egy stigmát, egy elóítéleten alapuló gondolkodást teremt. A maradék három kategória differenciált étékeket tartalmazott. A válaszadók kevesebb, mint fele gondolta úgy, hogy a rendvédelmi szerveknek nem probléma a prostitúció jelensége, azaz törvényi szinten, végrehajtó hatalmuknál fogva járnak el a prostituáltakkal, futtatókkal, és a résztvevőkkel szemben. Ez a válaszadók 45\%-át (45 főt) ölelte fel. A válaszadók több, mint fele viszont úgy gondolta - nem szignifikáns eltéréssel -, hogy a prostitúció jelensége leginkább a jogalkotónak és a civileknek jelent problémát. Ez a civil kör, az a kör, akik nem vesznek igénybe szexuális szolgáltatást, a jogalkotó pedig az a jogalkotó, amely jelenleg a prostitúció jelenségét félreglementációs és félabolícionista jellemzőkkel szabályozza. A válaszadók 57\%-a (57 fö), illetve 54\%-a (54 fö) döntött a moralitás e személyei mellett. 0 volt azoknak a száma viszont, akik úgy gondolták, hogy a multivállalatoknak okozna problémát a prostitúció jelensége, ezzel a felmérés minimumértékét határozták meg. A fentieket összehasonlítottam azon válaszadók demográfiai adataival, akik a szabályozási kérdéskörben: ${ }^{39}$ „Az ország, ahol élek a prostitúciót nem tiltja, viszont annak gyakorlását szabályokhoz köti, szükség esetén korlátozza, és büntetni rendeli” igenlő; „Az ország, amelyben élek a prostitúcióval kapcsolatos szabályozást a nemzetközi szabályozással nem hangolta össze, azok nem érvényesülnek" igenlő választ adtak. E személyek megegyeztek azon személyekkel, akik úgy gondolták, hogy a legnagyobb problémát ma Magyarországon a jogalkotási folyamatok okozzák, amelyek ok-okozati összefüggésben állnak a prostitúció társadalmi kirekesztettségével. A maximumérték 71, a minimumérték 0 volt.
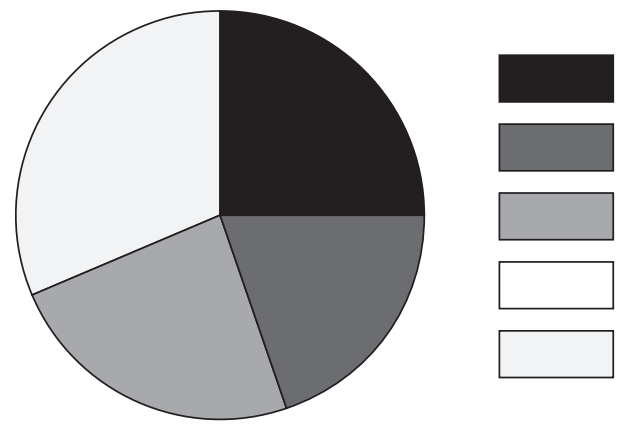

Leginkább a jogalkotóknak

Leginkább a rendvédelmi szerveknek Leginkább a civileknek

Leginkább a multivállalatoknak

Mindegyiknek, de nem az ügyféli körhöz tartozóknak

4. ábra: A moralitás személyei (akiknek leginkább probléma a prostitúció) (\%)

Forrás: a szerző szerkesztése

39 A jelen tanulmánynak nem képezi részét a kutatás szabályozási kérdéskörre vonatkozó részletes elemzése, így annak csak az ezzel párhuzamos és összevethető eredményeit közöltem. 


\subsubsection{A prostitúció megitélése}

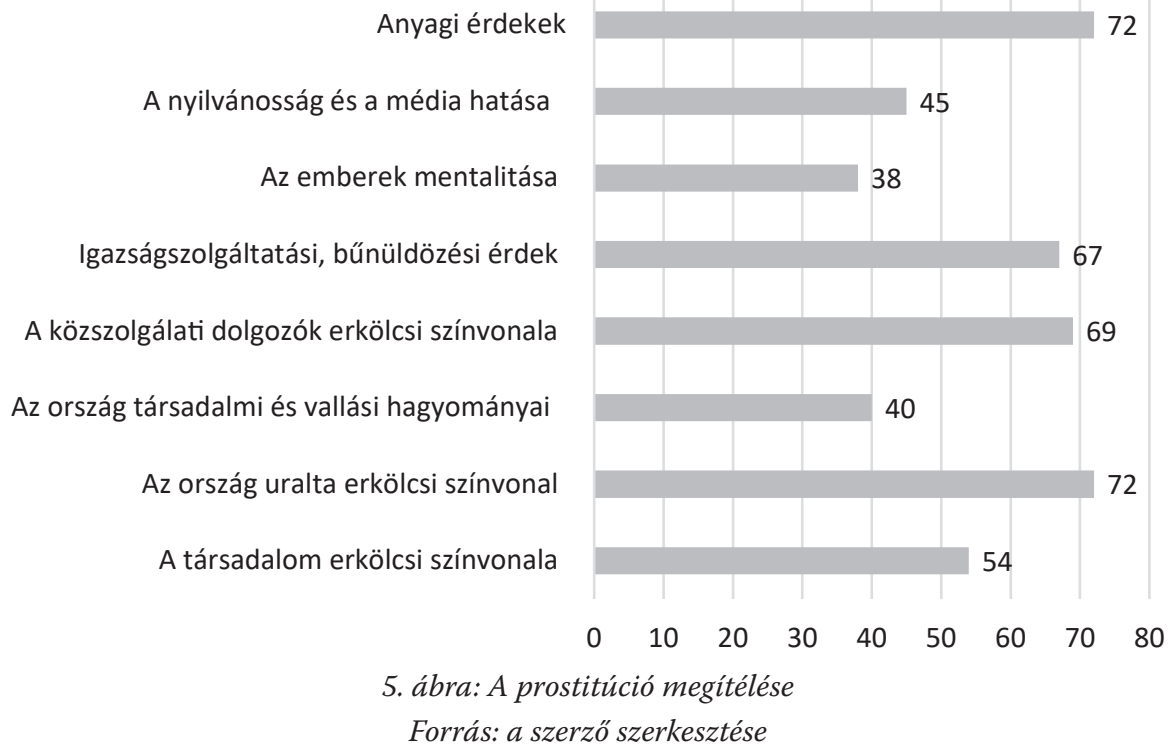

A feltett kérdés a prostitúció jelenségének résztvevő általi megítélésére vonatkozott. (A résztvevőnek növekvő számozással sorrendbe kellett állítania és véleményeznie, hogy szerinte a felsorolt tényezők közül melyik és milyen mértékben hat a prostitúció társadalmi megítélésére.) A leginkább jellemző tényezőt 1-es számmal, a legkevésbé jellemző tényezőt 8-as számmal kellett jelölnie, amelyben egy számot csak egyszer használhatott fel. (A végső eredményeket a sorrendiséget megalapozó személyek száma döntötte el, azaz az 1-től 8-ig terjedő értékeket manuálisan megszámoltam, hogy mely sorra hány fó hányas számmal szavazott.) Nyolc kategóriát állítottam fel: „a társadalom erkölcsi színvonala; az ország uralta erkölcsi színvonal; az ország társadalmi, és vallási hagyományai; a közszolgálati dolgozók erkölcsi színvonala; igazságszolgáltatási, bűnüldözési érdek; az emberek mentalitása; a nyilvánosság és a média hatása; anyagi érdekek". Két szélsőséges értéket vizsgálva a válaszadók szerint a prostitúció megítélésére leginkább és legjellemzőbb módon az hat, ha a háttérben azt anyagi érdekek mozgatják. A válaszadók 72\%-a, azaz a válaszadók közül 72 fő értékelte konzekvensen úgy, hogy a prostitúció jelenségének társadalmi minőségét anyagi érdekek formálják. Ezzel szemben 67 fó, azaz a felmérésben részt vevők 67\%-a gondolta úgy, hogy az igazságszolgáltatási, bủnüldözési érdekek határozzák meg legkevésbé, hogy a prostitúciónak a társadalomban milyen értékítélete lesz. Az ország uralta erkölcsi színvonal volt a második legjellemzőbb befolyásoló tényező, amelyre a résztvevők 72\%-a (72 fó) válaszolt. A felmérésben megszólaltatott prostituáltak úgy vélik, hogy a két szélsőséges értéken túlmenően, az anyagi kontroll, valamint az igazságszolgáltatási érdeken felül, a második leginkább befolyásoló tényező, hogy milyen az adott 
országban uralkodó erkölcsi ítélet. Ez nem az integritással, hanem az etikával és erkölccsel függ össze, hogy vajon a prostitúció az adott országban milyen értéket közvetít, és az egyáltalán illeszthető-e az adott ország magatartási szabályai közé, ha igen, akkor mennyire, ha pedig nem, akkor mennyire mély lesz a szakadék az elfogadás, a tolerancia és az elutasítás között. 54 fővel, azaz a megkérdezettek 54\%-ával folytatódott a súlyozás, amely szerint a harmadik ilyen tényező a társadalom erkölcsi színvonala. A felsorolásban a résztvevők többsége inkább hátrébb helyezi a társadalom erkölcsi megítélését, mint az országban uralkodó erkölcsi színvonalat. Ez azt sugallja, hogy egy adott ország uralta értékítélet (például hagyományok, korábbról fennmaradt normák stb.) igencsak befolyásolni képes a társadalom erkölcsi értékítéletét. Az etikai szabályok vonatkozásában viszont, amelyek még nem érik el a társadalomra kisebb vagy nagyobb fokban veszélyes büntetendő magatartások körét, differenciált gondolkodásmódot feltételez. Az etika és erkölcs személyre szabott, nem általánosítható. Más kultúrákból jöttünk, más magatartási szabályok között nőttünk fel. Az, amely értékadó és jogkövető, az kizárólag csak az adott ország által joganyagba emelt magatartási szabályok összessége lehet, etikai szabály nem. Ha a társadalomban etikai szabályt alkotunk, az nem lehet kötelező érvényü. A prostitúció ezáltal nem szükséges rossz, és problémaforrás, és nem feltétlenül deviancia. A válaszadók 40\%-a (40fó) gondolta úgy, hogy az ezt követő befolyásoló elem az országban uralkodó vallási nézet. A megkérdezettek 38\%-a szerint az emberek mentalitása szintén kevésbé jellemzője a megítélés mértékének, azt az ötödik helyre sorolták. 45\%, azaz 45 fö a megkérdezettek közül a média és a nyilvánosság hatását szintén a legkevésbé jellemzőnek tartották a prostitúció megítélése vonatkozásában. A közszolgálati dolgozók erkölcsi színvonala az utolsó előtti helyen szerepel, amely a megkérdezettek 69\%-át (69fó) ölelte fel. Az erkölcsi színvonal egy hármas sorrendet állított fel a prostitúció megitélésének tárgyában, amelynek élén az ország uralta, középütt a társadalom és a legalján a közszolgálati dolgozók erkölcsi színvonala szerepelt. A maximumérték 72\%, a minimumérték pedig $38 \%$ volt.

\subsection{Az eredmények értelmezése}

A kutatás a résztvevők saját, szubjektív megítélésén alapult, álláspontom szerint viszont a szubjektumokban rejlő kifejezések, attitűdök, az énmegjelenítés és a meggyőzés segíthet abban, hogy a tabuként kezelt témákat - mint például a prostitúció - jobban megismerjük. Az már a kutató felelőssége, hogy például a túlzásokkal - amplifikáció - mit kezd, és azt hogyan értelmezi a szövegkontextusokban. Ugyanakkor bizonyított eredmény, hogy az a dolgok tisztázásában és megvilágításában nagy szerepet játszik..$^{40} \mathrm{Ad}$ absurdum közelebb juttat az igazsághoz és a valósághoz, ami a tudományos kutatás feladata is egyben.

40 Richard M. Roberts - Roger J. Kreuz: Why Do People Use Figurative Language? Psychological Science, 5. (1994), 3. 159-163. 
A kutatási eredmények azt jelezték, hogy a prostituáltak úgy tekintenek magukra, mint a társadalom egy kirekesztett csoportjára, nem érzik úgy, hogy a reintegrációs folyamatok részesei lehetnének (moralitás $=100 \%$ ).

További eredmény, amelyet a kutatás sugallt, hogy a prostitúció jelensége a társadalom legtöbb tagjának problémát okoz, amely megalapozza az előítéletességen alapuló véleménynyilvánítást. Ez alól kivételt jelent az ügyféli kör, akik igénybe veszik a prostituáltak szolgáltatásait (moralitás személyei; mindenki, kivéve az ügyféli körhöz tartozók $=71 \%$ ). Mindezzel összefüggésben a kutatás rávilágított arra, hogy a társadalmi kirekesztettség alapjául szolgáló prostitúciót mint deviáns viselkedési formát csupán második helyen alakítja az adott ország, harmadik helyen pedig a társadalom erkölcsi színvonala (prostitúció megítélése; ország uralta erkölcsi színvonala $=72 \%$ ) (prostitúció megítélése; társadalom erkölcsi színvonala $=54 \%$ ). Ezeket előzi meg és ezzel a leginkább befolyásoló tényező az anyagi érdekek összhangja (prostitúció megítélése; anyagi érdekek $=72 \%$ ). Ezzel összefüggésben megjegyzendő, hogy, ha állami bordélyokat állítanánk fel, akkor abból az állam profitálna; ha illegális bordélyházak mủködnek, abból a szervezett bủnözés profitál; ha a jelenlegi szabályozást vesszük alapul, akkor az állam csak akkor profitálhat adók módjára a prostitúcióból, amennyiben azt a résztvevők megfizetik, de számos visszásság fedezhető fel e tekintetben. Ezért fontos, hogy az anyagi érdekek prioritása miben és hogyan nyilvánul meg, hol tetőzik. ${ }^{41}$

A kutatás arról informált, hogy az egyik minősített problémát a válaszadók szerint a jogalkotási folyamatok jelentik ${ }^{42}$ (moralitás személyei; jogalkotó > 54\%). Ezzel szorosan összefügg az igazságszolgáltatási, bűnüldözési érdek is, amely a szabályozás szerinti végrehajtó hatalmat gyakorolja, és így végrehajtási funkciójából adódóan a legkevésbé befolyásoló tényezője a deviancia kialakításának (prostitúció megítélése; igazságszolgáltatási, bűnüldözési érdek $=72 \%$ ). A bűnüldözés és az igazságszolgáltatás a törvényeknek alárendelt végrehajtó hatalma, így csakis a normákba foglalt jogosultságok gyakorlását, kötelmek teljesítését kell vizsgálnia, szükség esetén pedig szankcionálnia. Ha a jogalkotó a prostitúciót büntetendővé nyilvánítja, akkor az igazságszolgáltatás és a bünüldözés annak mentén köteles eljárni, annak körülményeit kell vizsgálnia. (Minderre a deviancia részben ismertetett jogi szabályozás az irányadó.) A közszolgálati dolgozók erkölcsi értékítélete például a deviancia és a társadalmi kirekesztettség sorrendjében csupán az utolsó előtti helyen szerepelt, így nem volt akkora befolyásoló tényező (prostitúció megítélése; közszolgálati dolgozók erkölcsi színvonala $=69 \%$ ).

41 Kovács István: Magyarország határain átnyúló szervezett bűnözés és prostitúciós bűncselekmények a schengeni térségben, különös tekintettel a SOCTA és EUROSTAT értékelésére. Határrendészeti Tanulmányok, 14. (2017), 4. 82-161.

42 A jogalkotási folyamatok a jelenlegi félreglementációs és félabolícionista modellek ötvözését jelentették. 


\section{6. Összegzés}

A lefolytatott vizsgálódás egy fontos forrás a prostitúció megítélése szempontjából. Az eredmények megmutatták, hogy a prostituáltak önmagukat valóban kirekesztettnek érzik, nézetükben az emberek a munkájukat erkölcsileg elítélik. Ennek centrális elemei közé tartozik a prostitúció szabályozása, valamint a normatív erkölcsi színvonal.

Közel 70 éves az a társadalmi vita, amely a New York-i Egyezmény aláírása óta eltelt, érdemes tehát elgondolkodnunk azon, hogy a prostitúció kezelésére rendelt hazai intézményrendszer korszerűsítése - jórészt a már említett nemzetközi joggal történő ellentmondások miatt - mennyire égető jelentőségủ: új felismerésekre és cselekvési alternatívákra van szükség. A felmérés, ha nem is reprezentatív módon, de figyelemfelhívás lehet a tekintetben is, hogy a jelenlegi szabályozás tovább mélyíti az így is elég mély szakadékot a prostituáltak és a társadalom között.

A jelenség kezelése önmagában is hosszú történelmi múltra tekint vissza, amely megmutatta, hogy a legkülönfélébb szabályozási formák sem képesek arra, hogy egyedül megoldást nyújtsanak. A megoldáshoz nagyban hozzájárulhat a prostitúció jelenségével kapcsolatos tények kellő komolysággal, felelősséggel és szakszerűséggel történő kezelése, valamint a társadalmi szolidaritás összhangja.

Álláspontom szerint a társadalom által kirekesztett populációk vonatkozásában még inkább toleránsabb bánásmódot kell gyakorolnunk, és még inkább figyelnünk kell arra, hogy az alapvető alkotmányos és emberi jogok gyakorlását részükre biztosítsuk. Ahhoz, hogy ezek a csoportok a társadalom újbóli tagjai lehessenek, reintegrációs és reszocializációs intézkedéseket kell alkalmaznunk és paradigmaváltást szorgalmaznunk az elöítéletekkel szemben.

\section{Irodalomjegyzék}

Andorka Rudolf: Bevezetés a szociológiába. Budapest, Osiris, 2006.

Andorka Rudolf - Buda Béla - Cseh-Szombathy László: A deviáns viselkedés szociológiája. Budapest, Gondolat, 1974.

Balogh Sándor - Pallagi Anikó: A deviancia, az egyes deviáns magatartások. Rendvédelmi Füzetek, (2001), 47. 1-20.

Bodor Endre - Szücs János: A prostitúció helyzete a fővárosban. Belügyi Szemle, 2. (1964), 6. 27-34.

Borai Ákos: Prostitúció. Kecskemét, Print 2000 Nyomda Kft., 2003.

Buckman, Charles G.: The English Convict. A Statistical Study. Virginia, General Books, 2010.

Bódis Enikő: Prostituált narratívák. In Fehér Lenke (szerk.): Adás-vétel-konferencia a prostitúcióról. Budapest, Országos Kriminológiai Intézet, 2011. 14-20.

Cohen, Jacob: The earth is round ( $\mathrm{p}<.05)$. American Psychologist, 49. (1994), 12. 997-1003. DOI: https://doi.org/10.1037/0003-066X.49.12.997

Cseh-Szombathy László - Ferge Zsuzsa: A szociológiai felvétel módszerei. Budapest, Közgazdasági és Jogi Könyvkiadó, 1971.

Durkheim, Émile: A társadalmi tények magyarázata. Budapest, Közgazdasági és Jogi Könyvkiadó, 1978. 
Ekberg, Gunilla: Nemzetközi vita a prostitúcióról és nőkereskedelemről: az érvek cáfolata. In Forgács Zsuzsa - Juhász Géza (szerk.): Szeminárium a prostitúció törvényesitésének hatásairól. Budapest, 2004, 1-70.

Enyedi György - Tamási Péter: Népbetegségeink? - A társadalmi beilleszkedési zavarok anatómiájához. Info-Társadalomtudomány, (1987), 2.3-8.

Farkas Zoltán - Lombos Lajos: A prostitúció elleni intézkedések. Rendőrségi Szemle, 5. (1957), 10. 672-680.

Farkas Zoltán: A racionális cselekvés, társadalmi cselekvés és kölcsönhatás. Társadalomelmélet 5. Miskolci Egyetem, 2006.

Farley, Melissa: Prostitution and the Invisibility of Harm. Women \& Therapy, 26. (2003), 3-4. 247-280. DOI: https://doi.org/10.1300/j015v26n03_06

Forrai Judit: Visszatekintés a budapesti prostitúció múltjára. Belügyi Szemle, 45. (1997), 5. 105-119. Forrai Judit: Prostituáltak mentális problémáinak elmélete és különböző tények feltárásának kezdetei a 19. században. Magyar Onkológia, 55. (2011), 3. 222-223.

Gönczöl Katalin: A bűnözés kontrollja: kriminálpolitika. In Gönczöl Katalin - Kerezsi Klára - Lévay Miklós (szerk.): Kriminológia. Budapest, Wolters Kluwer, 2019.

Gönczöl Katalin: Devianciák, devianciakontroll, bűnmegelőzési stratégiák. In Gönczöl Katalin - Korinek László - Lévai Miklós: Kriminológiai ismeretek, bünözés, bünözéskontroll. Budapest, Corvina, 1996. 119-134.

Hortobágyi Richárd: Prostitúció egy ipari nagyvárosban. Belügyi Szemle, 9. (1971), 5. 120-121.

Irk Ferenc: Deviancia, bűn, bűncselekmény, makrokriminalitás. Jogtudományi Közlöny, 69. (2014), 4. $180-186$.

Juhász Géza: Hogyan hátráltatja a nőkereskedelem felszámolását a nők emberi jogai iránt érzéketlen magyar büntetőjogi szemlélet? Budapest, Habeas Corpus Munkacsoport, 2004.

Kovács István: Magyarország határain átnyúló szervezett bünözés és prostitúciós bűncselekmények a schengeni térségben, különös tekintettel a SOCTA és EUROSTAT értékelésére. Határrendészeti Tanulmányok, 14. (2017), 4. 82-161.

Kovács István: Egy empirikus kutatás részletei: a prostitúció jelensége és társadalmi kontrollja napjainkban. Budapest, Dialóg Campus, 2019.

Lévay Miklós: Társadalmi kirekesztődés és bűnözés. A rendszerváltozás utáni kriminálpolitikai megközelítések Magyarországon és a társadalmi kirekesztődés. In Borbíró Andrea - Kerezsi Klára (szerk.): A kriminálpolitika és a társadalmi bünmegelözés kézikönyve I. Budapest, Igazságügyi és Rendészeti Minisztérium, 2009. 87-108.

Lombroso, Cesare: L’uomo delinquente. Milan, Hoepli, 1876.

Merényi Kálmán: Társadalmi beilleszkedési zavarok napjainkban Magyarországon. Acta Universitatis Szegediensis: Acta Juridica et Politica, 74. (2012), 321-330.

Merton, Robert K.: Középszintű szociológiai elméletek. In Robert K. Merton (szerk.): Társadalomelmélet és társadalmi struktúra. Budapest, Gondolat, 1980. 83-141.

Molnár Lajos: Az erkölcsök, a közegészség és a prostitúció. Budapesti Negyed, 18. (2010), 3. 67-101.

Nairne D.: We want the power: Findings from focus group discussions in Hillbrow, Johannesburg. Research for Sex Work, (2000), 3. 3-5.

Pataki Ferenc: A kutatások néhány tapasztalata. Info-Társadalomtuduomány, (1987), 2. 9-17.

Hynes, H. P. - C. Raymond: Put in harm's way: the health consequences of sex trafficking in the United States. In J. Silliman - A. Bhattacharjee (szerk.): Policing the national body: Sex, race, and criminalization. Cambridge, MA, South End, 2002. 197-229. 
Richter, Marlise: Sex work, reform initiatives and HIV, AIDS in inner city Johannesburg. African Journal of AIDS Research, 7. (2008), 3. 323-333. DOI: https://doi.org/10.2989/ajar.2008.7.3.9.656

Morse, Edward V. - Patricia M. Simon - Howard J. Osofsky - Paul M. Balson - H. Richard Gaumer: The male street prostitute: A vector for transmission of HIV infection into the heterosexual world. Social Science and Medicine, 32. (1991), 5. 535-539. DOI: https://doi.org/10.1016/02779536(91)90287-m

Roberts, Richard M.- Roger J. Kreuz: Why do people use figurative language? Psychological Science, 5. (1994), 3. 159-163. DOI: https://doi.org/10.1111/j.1467-9280.1994.tb00653.x

Smith, Michael D. - Christian Grov -David W. Seal - Peter McCall: A Social-Cognitive Analysis of How Young Men Become Involved in Male Escorting. The Journal of Sex Research, 50. (2013), 1. 1-10. DOI: https://doi.org/10.1080/00224499.2012.681402

Tartsányi Miklós: Falusi lány Pesten. Csendörségi Lapok, 34. (1944), 14. 6-10.

Weininger, Otto: Anyaság és prostitúció. Budapesti Negyed, 18. (2010), 3. 385-391. 